\title{
Microbiological quality of retail fresh fish fillets in The Netherlands
}

\author{
M.J.M. van den Broek ${ }^{1}$, D.A.A. Mossel ${ }^{1}$ and H. Mol ${ }^{2}$ \\ ' Department of the Science of Food of Animal Origin, Faculty of Veterinary Medicine, University of Utrecht, \\ P.O. Box 80175, 3508 TD Utrecht, The Netherlands and '2 Food Inspection Service Utrecht, Nijenoord 6 , \\ 3552 AS Utrecht, The Netherlands
}

(Received 26 November 1983; accepted 30 January 1984)

\begin{abstract}
A total of 242 samples of ready-for-sale fish fillets of validated good sensory quality was examined for colony counts at 20,30 and $37^{\circ} \mathrm{C}$, Enterobacteriaceae at $37^{\circ} \mathrm{C}$, Escherichia coli. Salmonella and Vibrio parahaemolyticus in $10 \mathrm{~g}$ aliquots, Staphylococcus aureus and yeast and mould propagules. Gram negative pathogens were not detected in any sample. The following reference values were found attainable: colony counts at $30^{\circ} \mathrm{C}, 10^{6} \mathrm{~g}^{-1}$; Enterobacteriaceae $10^{3} \mathrm{~g}^{-1}$; E. coli $10 \mathrm{~g}^{-1} ; S$. aureus $10^{2} \mathrm{~g}^{-1}$; yeast and mould propagules $10^{4} \mathrm{~g}^{-1}$. These reference values include, as customary, a tolerance of about $20 \%$ of samples exceeding the stated levels without, however, reaching the next $\log _{10}$ level.
\end{abstract}

Key words: Fresh fish fillets; Microbiological reference values

\section{Introduction}

During the filletting of fish as practised in filletting plants or shops, it is impossible to avoid contamination of the initially virtually sterile fish flesh (Shewan, 1961).

The main sources of contamination are (i) skin and gut contents of the fish; (ii) inadequately cleaned fish cases, filletting boards and knives; and (iii) the hands of those preparing and handling the fillets. Subsequently, this primary contamination will proliferate, depending on storage conditions. The aim of this investigation was to assess the degree of bacterial colonisation of fresh fillets offered for sale to the consumer. In the Dutch Food \& Commodities Act (Warenwet, 1983) no criteria are given for the microbiological condition of fish and fish products. Only the general requirements for food apply, i.e. fish must be of good quality and not present public health risks. The data collected in our survey might prompt future legislation to be more precise. 


\section{Materials and Methods}

\section{Materials}

All fish landed in The Netherlands has to pass the auction where the fish is inspected by the regional Food Inspection Service. After passing the auction the fish is transported by fish monger companies to fish filletting plants or to local retailers where filletting takes place. Samples of fresh, ready-for-sale marine fish fillets of good sensory quality were procured from retail stores in Utrecht and suburbs. Though it was unknown how the fillets had been manufactured and stored before selling, inspectors of the staff of the Food Inspection Service at Utrecht validated their good condition before the samples were subjected to bacteriological examination. During a period of 6 years, a total number of 242 samples was collected which included cod (72), plaice (51), coal fish (21), whiting (21), haddock (24), sole (15) and 38 samples of other kinds of marine fish.

All samples were transported to the laboratory in an insulated box with melting ice and examined bacteriologically on the day of sampling.

\section{Methods}

From all fillet samples decimal dilution series were prepared by macerating $20 \mathrm{~g}$ with $180 \mathrm{ml}$ peptone saline in a stomacher (Colworth) for $2 \mathrm{~min}$ and subsequently preparing further dilutions using tubes containing $9 \mathrm{ml}$ peptone saline. The numbers of colony-forming units (cfu) were determined or presence or absence tests were carried out to assess the following groups of bacteria:

1. Aerobic bacteria grown at $20^{\circ} \mathrm{C}$ (incubation for 5 days), $30^{\circ} \mathrm{C}$ ( 3 days) and $37^{\circ} \mathrm{C}$ ( 1 day), in all instances using poured plates of plate count agar (Oxoid, CM 325). However, colony counts were not always made from the samples at all temperatures.

In order to evaluate the effect of a poured plate procedure compared to a spread plate method and of the addition of sodium chloride to the medium, numbers of cfu were determined in 25 samples of fish fillet (both from flat fish and round fish) collected under the same conditions as described above. For each sample cfu counts were assessed in and on plate count agar (Oxoid CM 325) with and without sodium chloride $(1 \%)$ after incubation at $20^{\circ} \mathrm{C}$ (5 days), $30^{\circ} \mathrm{C}$ ( 3 days) and $37^{\circ} \mathrm{C}(1$ day).

2. Enterobacteriaceae (Mossel et al., 1979): using layered poured plates of Violet Red Bile Glucose Agar (Oxoid, CM 485) incubated overnight at $37^{\circ} \mathrm{C}$. After colony counting, numbers of colonies equal to the square roots of those in plates containing between 30 and 300 colonies were selected at random and examined for oxidase activity and fermentative dissimilation of glucose. For this purpose the so-called Gram-negative diagnostic tubes containing a bottom layer of Violet Red Bile Glucose Agar, an intermediate layer of water agar and a top layer of SIM-agar (Mossel et al., 1977) were used.

3. Escherichia coli: using layered poured plates of Violet Red Bile Agar (Difco 0012-01) incubated overnight at $37^{\circ} \mathrm{C}$. The same representative proportion of 
colonies as indicated under 2 was examined for oxidase reaction, gas formation in Brilliant Green Bile (2\%) Broth (Oxoid CM 31) and indole formation in Tryptone Water (Oxoid CM 87), both at $44^{\circ} \mathrm{C}$ (Mossel et al., 1979).

4. Samples of $10 \mathrm{~g}$ of fish fillet were examined for Salmonella (Edel and Kampelmacher, 1973). After preenrichment in Buffered Peptone Water (Oxoid CM 509) for $18-24 \mathrm{~h}$ at $37^{\circ} \mathrm{C}$ enrichment was carried out in Tetrathionate Broth (Oxoid CM 29) incubated for $18-24 \mathrm{~h}$ at $43^{\circ} \mathrm{C}$. Subcultures were made on Brilliant Green Agar (Oxoid CM 329) incubated for $18-24 \mathrm{~h}$ at $37^{\circ} \mathrm{C}$. Suspect colonies were tested for agglutination with polyvalent Salmonella serum (National Institute of Public Health, Bilthoven, The Netherlands), and when required with group sera.

5. Vibrio parahaemolyticus was initially (1977-1978) searched for in $10 \mathrm{~g}$ of fish fillet by enrichment in 5\% NaCl-Meat Broth for $18-24 \mathrm{~h}$ at $37^{\circ} \mathrm{C}$ (Kampelmacher et al., 1970, 1972). After this technique had been found insufficiently productive (van den Broek et al., 1979a) 110 samples were resuscitated in Tryptone Soya Broth (Oxoid $\mathrm{CM} 129$ ) with $2 \% \mathrm{NaCl}$ for $2 \mathrm{~h}$ at room temperature and then cultured overnight in Horie's Arabinose Ethylviolet Broth (Horie et al., 1964) at $37^{\circ} \mathrm{C}$. Subcultures were in all instances made on TCBS-Agar (Oxoid CM 333) incubated overnight at $37^{\circ} \mathrm{C}$ (Kampelmacher et al., 1970, 1972). Suspect green colonies were examined as described by van den Broek et al. (1979a).

6. Staphylococcus aureus: using spread drop plates of Baird-Parker Medium (Oxoid CM 275) incubated for $30-48 \mathrm{~h}$ at $37^{\circ} \mathrm{C}$. Examination of typical colonies was carried out according to the following criteria: growth at $43^{\circ} \mathrm{C}$ in $\mathrm{BHI}-\mathrm{Broth}$ (Oxoid CM 225), fermentative attack on glucose, catalase and coagulase tests (Bouwer et al., 1982).

7. Yeasts and moulds: using spread drop plates of Oxytetracycline-Glucose-Yeast Extract Agar (Oxoid CM 545) incubated at $20^{\circ} \mathrm{C}$ for 5 days (Mossel et al.. 1975). No differentiation was made between mould and yeast colonies.

\section{Results and discussion}

Aerobic colony counts at 20,30 and $37^{\circ} \mathrm{C}$

General - The results obtained are summarized in the form of frequency distributions in Table I.

TABLE I

Distribution of aerobic colony counts at 20,30 and $37^{\circ} \mathrm{C}$ in $1 \mathrm{~g}$ fish fillet.

\begin{tabular}{rccc}
\hline cfug $^{-1}$ & $20^{\circ} \mathrm{C}(n=242)(\%)$ & $30^{\circ} \mathrm{C}(n=96)(\%)$ & $37^{\circ} \mathrm{C}(n=196)(\%)$ \\
\hline$\leq 10^{5}$ & 3 & 3 & 58 \\
$10^{5}-10^{6}$ & 20 & 41 & 35 \\
$10^{6}-10^{7}$ & 59 & 48 & 6 \\
$10^{7}-10^{8}$ & 17 & 8 & 1 \\
$\geq 10^{8}$ & 1 & 0 & 0 \\
\hline
\end{tabular}


Significant differences in the levels of colonisation could not be found for year(s) of sampling or type of fish.

All colony counts obtained represent only a part of the total colonisation of the fish fillets. This results from the following phenomena (i) plate count agar is a relatively poor medium; (ii) the medium does not contain sodium chloride, and consequently inhibits typical marine bacteria (Leifson, 1968); and (iii) pouring of plates can be detrimental to heat-sensitive psychrotrophic bacteria by causing lethal or sublethal damage (Stapert et al., 1962). This applies to psychrotrophic Pseudomonas and Acinetobacter species which belong to the predominant fish spoilage organisms in the North-West European region (Skovgaard, 1979). In iced round fish these bacteria lead to the formation of trimethylamine (TMA), which is currently used as an indicator of spoilage. In addition, fastidious types of organisms like Photobacterium and Lucibacterium spp. can be responsible for spoilage under certain, i.e. anaerobic conditions (van Spreekens, 1974; Skovgaard, 1979). These bacteria cannot grow in plate count agar without sodium chloride and will, moreover, be damaged by exposure to heat as happens in a poured plate procedure (van Spreekens, 1974).

The results of assessing the effects of the use of poured plates instead of spread plates and of the addition of sodium chloride on the numbers of cfu are summarized in Table II.

Though there was a trend in drop counts and addition of $\mathrm{NaCl}$ to slightly increased colony counts at $20^{\circ} \mathrm{C}$ the differences were of no practical significance.

Counts at $20^{\circ} \mathrm{C}$ - The explanation for observing the highest counts at $20^{\circ} \mathrm{C}$ must be found in the nature of the spoilage flora of the fish examined. It originates partly from the North Sea where water temperatures fluctuate between $4^{\circ}$ and $20^{\circ} \mathrm{C}$. Therefore, the bacterial flora consists mainly of organisms adapted to low temperatures. During cold storage of fish in a chill room or in melting ice these bacteria will grow, and together with those acquired by contact with contaminated surfaces on board ships or ashore they form the natural spoilage flora in fish (van Spreekens, 1977). During filletting more spoilage bacteria will contaminate the fish flesh from debris and slime on filletting boards and knives and from the filletters' hands.

Counts at $30^{\circ} \mathrm{C}$ - The number of cfu $\mathrm{g}^{-1}$ at $30^{\circ} \mathrm{C}$ found in our survey did not exceed $10^{7}$ in $92 \%$ of the samples $(n=96)$; in $44 \%$ it was $<10^{6}$.

\section{TABLE II}

Geometric means of $\mathrm{cfu} \mathrm{g}^{-1}$ determined at 20,30 and $37^{\circ} \mathrm{C}$ by poured and spread plate techniques, respectively with and without $1 \%$ sodium chloride. 25 samples of fresh fish fillet.

\begin{tabular}{lllll}
\hline $\begin{array}{l}\text { Temp. } \\
\left({ }^{\circ} \mathrm{C}\right)\end{array}$ & $\mathrm{PCA}^{\mathrm{a}}$ & \multicolumn{3}{l}{$\mathrm{PCA}+1 \% \mathrm{oNaCl}$} \\
\cline { 2 - 5 } & Poured plate & Spread plate & Poured plate & Spread plate \\
\hline 20 & 6.8 & 6.9 & 6.9 & 7.0 \\
30 & 6.5 & 6.6 & 6.7 & 6.7 \\
37 & 5.3 & 5.3 & 5.7 & 5.7 \\
\hline
\end{tabular}

a Plate count agar. 
The reference value used by the Food Inspection Service in Utrecht according to suggestions by Mossel and Tamminga (1980) is $10^{6} \mathrm{cfu}^{-1}$ allowing $20 \%$ variation between $10^{6}$ and $10^{7}$. This value seems realistic in view of our results of the colony counts at $30^{\circ} \mathrm{C}$. For deep frozen fillets the Institute for Fishery Products at IJmuiden, The Netherlands, even applies $5 \times 10^{5} \mathrm{~g}^{-1}\left(\mathrm{PCA}, 15^{\circ} \mathrm{C}\right.$ ) as a standard, because in their experience this value can be achieved by hygienic preparation of fillets (van Spreekens, 1981, personal communication).

To attain the best possible bacteriological condition of fish fillets it is essential to start with freshly caught fish, consistently cooled in ice of good bacteriological quality (Georgala, 1957, Shewan, 1961). Before filletting, the fish must be washed thoroughly in clean drinking water to keep contamination of the fish flesh during filletting as low as possible (Georgala, 1957). Filletting itself must be done on cutting boards made of synthetic material under running water. The cutting boards and other utensils must be cleaned and disinfected daily and the fillets must be cooled immediately after cutting. These measures in combination represent good manufacturing practice (GMP) on which reference values can be based.

Counts at $37^{\circ} \mathrm{C}$ - The numbers of $\mathrm{cfu} \mathrm{g}^{-1}$ at $37^{\circ} \mathrm{C}$ are obviously lower than those at 20 or $30^{\circ} \mathrm{C}$ : $58 \%$ of 196 samples were below $10^{5} \mathrm{~g}^{-1}$ and $93 \%$ did not exceed $10^{6}$. Our data substantiate those of Shewan (1961) obtained in fish caught in more northern waters. Mesophilic bacteria on or in fish mostly originate from warmblooded animals or man, being transferred by direct contact and coastal waters contaminated with unpurified sewage (Ayres, 1975). During cold storage these bacteria will not proliferate.

\section{Enterobacteriaceae}

Assessments of the levels of Enterobacteriaceae in foods allow an estimation of their general bacteriological condition ('indicator' function) and to a certain extent the risk of presence of pathogenic enteric organisms ('index' function) (Mossel, 1982).

\section{TABLE III}

Number of cfu of Enterobacteriaceae $\mathrm{g}^{-1}$ fish fillet. Percentage of samples classified within the levels indicated.

\begin{tabular}{cc}
\hline $\mathrm{cfu} \mathrm{g}^{-1}$ & Total $(n=217)($ o) \\
\hline$<10^{2}$ & 23 \\
$10^{2}-10^{3}$ & 43 \\
$10^{3}-10^{4}$ & 24 \\
$10^{4}-10^{5}$ & 9 \\
$\geq 10^{5}$ & 1 \\
\hline
\end{tabular}

Because in cold-stored foods psychrotrophic Enterobacteriaceae can predominate (for which the natural reservoir is not the faecal flora of man or animals but rather the environment of the processing plants) our Enterobacteriaceae counts were made 
at $37^{\circ} \mathrm{C}$ and are presented in summarized form in Table III. All counts listed should be considered as being 'confirmed' in the sense mentioned above.

The level of contamination of the open sea with Enterobacteriaceae is generally negligible compared with that near the coast. This can be partially explained from the effect of dilution that occurs by mixing coastal water with clean water at greater distances off the coast. In addition, it is known that seawater exerts a bacteriostatic and sometimes even a bactericidal effect on Enterobacteriaceae (de Balsac et al., 1952, Dawe and Penrose, 1978, Kampelmacher et al., 1973). Fish fillets will hence become contaminated with Enterobacteriaceae mainly during or after filletting, e.g. by contaminated fish skin. However, the main source must be the direct contact of fillets with contaminated surfaces, tools or hands. Adopting a reference value of $10^{3}$ $\mathrm{g}^{-1}$ Enterobacteriaceae with the usual tolerance (Mossel and Tamminga, 1980), over $70 \%$ out of 217 samples comply with this value. There was no indication of seasonal variations.

\section{E. coli}

In 14 out of 217 fish fillet samples $(6.5 \%) E$. coli was detected in numbers exceeding $10 \mathrm{~g}^{-1}$. In 9 of these $14 \mathrm{E}$. coli positive samples a relatively high count of Enterobacteriaceae was also found. The highest number of $E$. coli $\mathrm{cfu}^{-1}$ detected in this investigation was $2.0 \times 10^{5}$. An Enterobacteriaceae cfu count of $3.2 \times 10^{5}$ was found in the same sample.

All counts mentioned here should be considered as being 'confirmed' in the sense mentioned above.

Consequently a limit of $10 \mathrm{~g}^{-1} \mathrm{E}$. coli would be easily attainable by 'good manufacturing practices' in the case of fish fillets.

\section{Salmonella}

Salmonella infection transmitted by fish occurs only sporadically (Anonymous, 1977, Turnbull and Gilbert, 1982, Gilbert, 1983). In agreement with these epidemiological data, Salmonella could not be detected in any of the $21710 \mathrm{~g}$ samples of fish fillet which were examined in this survey.

\section{V. parahaemolyticus}

In previous investigations (van den Broek et al., 1979a, b; Kampelmacher et al., 1970, 1972) V. parahaemolyticus was detected in fish and shellfish landed from the North Sea - though infrequently and in low numbers only. The possibility of infection by $V$. parahaemolyticus transmitted by sea food in North West Europe however, was proven by an outbreak which occurred in England in 1974. Consumption of crab caught in British waters was aetiologically involved (Hooper et al.. 1974).

In this investigation $V$. parahaemolyticus could not be detected in any of the 217 $10 \mathrm{~g}$ samples of fish fillet examined. Our results and the low numbers and low 
frequency of occurrence of $V$. parahaemolyticus in seafood from the North Sea previously encountered substantiate that the risk of gastroenteritis due to $V$. parahaemolyticus is very remote in the countries of North West Europe.

\section{S. aureus}

S. aureus is not a natural inhabitant of seawater or fish. Therefore, the presence of high numbers of these bacteria on fish fillets is a result of contamination originating from human skin or respiratory tract, followed by proliferation due to storage at ambient temperatures.

The results obtained in the present survey are presented in Table IV. All cfu counts listed here should be considered as being 'confirmed' as described above. Out of 217 fish fillet samples $22 \%$ contained $10^{2}$ or more cfu $\mathrm{g}^{-1} \mathrm{~S}$. aureus. The reference value for $S$. aureus in raw fish according to Mossel and Tamminga (1980) is $10^{2} \mathrm{~g}^{-1}$, while The Food Inspection Service in Utrecht applies $5 \times 10^{2}$ as a limit for food in general. The latter reference value was exceeded in $15 \%$ of the samples. Such relatively high colony counts of $S$. aureus were also occasionally observed in a recent survey made by Abeyta (1983). They are the consequence of employees' unsanitary practices during filletting enhanced by temperature abuse, i.e. storage of fillets at ambient temperatures.

TABLE IV

Number of cfu of $S$. aureus $\mathrm{g}^{-1}$ fish fillet. Percentage of samples classified within the levels indicated.

\begin{tabular}{cc}
\hline cfu $^{-1}$ & Total $(n=217)(\%)$ \\
\hline$<10^{2}$ & 78 \\
$10^{2}-5 \times 10^{2}$ & 7 \\
$5 \times 10^{2}-10^{3}$ & 6 \\
$10^{3}-10^{4}$ & 7 \\
$\geq 10^{4}$ & 2 \\
\hline
\end{tabular}

The highest count of $S$. aureus observed was $5 \times 10^{4} \mathrm{~g}^{-1}$ in one sample, without counts of Enterobacteriaceae and/or aerobic colony counts at $37^{\circ} \mathrm{C}$ being significantly higher than in other samples. Hence incidental unacceptable contamination rather than temperature abuse must have caused this surprisingly high count.

Based on our results, a $S$. aureus count in fish fillet of less than $5 \times 10^{2} \mathrm{~g}^{-1}$ seems attainable in practice.

\section{Yeasts and moulds}

Yeasts and moulds belong to the normal microbial flora in cold-storage rooms and on moist surfaces. Therefore contamination with this type of microorganism and subsequent growth are nearly inevitable during storage of unpacked foods in cold stores. High counts of yeasts and moulds on fish fillets could however be an 
indication of too long a period of storage and/or storage at too high temperatures.

The results of our investigation are presented in Table V. No differentiation has been made between yeasts and moulds. From these results it can be concluded that the numbers of yeasts and moulds in fish fillet can vary greatly. The results showed a much narrower range for winter samples than for those collected during the summer.

\section{TABLE $V$}

Number cfu of yeasts and moulds $\mathrm{g}^{-1}$ fish fillet.

Percentage of samples classified within the levels indicated.

\begin{tabular}{rl}
\hline cfu $^{-1}$ & Total $(n=123)(\%)$ \\
\hline$<10^{2}$ & 10 \\
$10^{2}-10^{3}$ & 11 \\
$10^{3}-10^{4}$ & 59 \\
$\geqq 10^{4}$ & 20 \\
\hline
\end{tabular}

Efforts should be made by the trade to apply practices leading to mould propagule counts below $10^{3}$ and yeast cfu counts less than $10^{4} \mathrm{~g}^{-1}$.

\section{Acknowledgements}

The authors are greatly indebted to Miss Kitty J.A. van Spreekens, M. Sc., for guidance in this investigation. They also extend their gratitude to Miss A. Eggenkamp, Mr. J. Dekker and Mr. S. Kocsis for expert technical assistance.

\section{References}

Abeyta, C., 1983. Bacteriological quality of fresh seafood products from Seattle retail markets. J. Food Protection 46, $901-909$.

Anon., 1977. Salmonella Surveillance in 1974. Wkly Epidem. Rec. 52, 53-61.

Ayres, P.A., 1975. The quantitative bacteriology of some commercial bivalve shellfish entering the British markets. J. Hyg. Camb. 74. 431-440.

De Balsac, H., G. Bertozzi and L. Gondin, 1952. Pouvoir antibiotique des eaux de mer vis-à-vis de germes d'origine enterique, déversés par les effluents pollués des villes. Bull. Acad. Med. Paris 136, 512-514.

Bouwer-Hertzberger, S.A., D.A.A. Mossel and P.G.H. Bijker, 1982. Quantitative isolation and identification of Staphylococcus aureus. In: The isolation and identification of food-poisoning organisms, edited by J.E.L. Corry, D. Roberts and F. Skinner, Academic Press, London, pp. 165-172.

Dawe, L.L. and W.R. Penrose, 1978. 'Bactericidal' property of seawater: Death or debilitation. Appl. Environ. Microbiol. 35, 829-833.

Edel, W. and E.H. Kampelmacher, 1973. Comparative studies on the isolation of 'sublethally injured' Salmonellae in nine European laboratories. Bull. Wld. Hith. Org. 48, 167-174.

Georgala, D.L., 1957. Changes in the skin flora of cod after washing and icing. J. Appl. Bact. 20, $23-29$.

Gilbert, R.J., 1983. In: Food microbiology advances and prospects, edited by T.A. Roberts and F.A. Skinner, Academic Press, London, p. 46 et seq.

Hooper, W.L., G.I. Barrow and D.J.N. McNab, 1974. Vibrio parahaemolyticus food poisoning in Britain. Lancet, $i, 1100-1102$. 
Horie, S., K. Saheki, T. Kozima, M. Nara and Y. Sekine, 1964. Distribution of Vibrio parahaemolvticus in plankton and fish in the open sea. Bull. Jpn. Soc. Sci. Fish. 30, 786-791.

Kampelmacher, E.H., D.A.A. Mossel, L.M. van Noorle-Jansen and H.M. Vincentie. 1970. A survey on the occurrence of Vibrio parahaemolyticus on fish and shellfish marketed in the Netherlands. J. Hyg. Camb. 6R, 189-196.

Kampelmacher, E.H., L.M. van Noorle-Jansen, D.A.A. Mossel and F.J. Groen, 1972. A survey on the occurrence of Vibrio parahaemolyticus and $V$. alginolyticus on mussels and oysters and in estuarine waters in the Netherlands. J. Appl. Bacteriol. 35, 431-438.

Kampelmacher, E.H., A.W. Fonds und L.M. van Noorle-Jansen, 1973. Bakteriologische Untersuchungen von Meerwasser entlang der niederländischen Küste in den Jahren 1971 und 1972. Zbl. Bakteriol. Hyg. 1. Abt. Orig. B 157, 313-327.

Leifson, E., 1968. Motile marine bacteria. IIl. Effect of storage of seawater and source of isolation. Appl. Microbiol. 16, 1633-1634.

Mossel, D.A.A., 1982. Marker (index and indicator) organisms in food and drinking water. Semantics, ecology, taxonomy and enumeration. Antonie van Leeuwenhoek, 48, 609-611.

Mossel, D.A.A., C.L. Vega and H.M.C. Put, 1975. Further studies on the suitability of various media containing antibacterial antibiotics for the enumeration of moulds in food and food environments. $J$. Appl. Bacteriol. 39, 15-22.

Mossel. D.A.A.. I. Eelderink and J.P. Sutherland. 1977. Development and use of single 'polytropic' diagnostic tubes for the approximate taxonomic grouping of bacteria isolated from foods, water and medicinal preparations. Zentralbl. Bakteriol. Hyg., Abt. I, Orig. A. 278, 66-79.

Mossel, D.A.A., I. Eelderink, M. Koopmans and F. van Rossum, 1979. Influence of carbon source, bile salts and incubation temperature on the recovery of Enterobacteriaceae from foods using MacConkey-type agars. J. Food Protection 42, 470-475.

Mossel, D.A.A. and S.K. Tamminga, 1980. Methoden voor het microbiologisch onderzoek van levensmiddelen, P.C. Noordervliet, Zeist. 322 pp.

Shewan, J.M., 1961. The microbiology of seawater fish. In: Fish as Food, edited by G. Borgstrom, Academic Press, London. Vol. 1, pp. 487-560.

Skovgaard, N., 1979. Bacterial association of and metabolic activity in fish in North Western Europe. Arch. Lebensmittelhyg. 30, 106-109.

Stapert, E.M., W.T. Sokolski and J.I. Northam, 1962. The factor of temperature in the better recovery of bacteria from water by filtration. Can. J. Microbiol. 8, 809-810.

Turnbull, P.C.B. and R.J. Gilbert, 1982. Fish and shellfish poisoning in Britain. In: Adverse effects of foods, edited by E.F.P. Jeliffe and D.B. Jeliffe, Plenum. New York, pp. 297-306.

van den Broek, M.J.M., D.A.A. Mossel and A.E. Eggenkamp, 1979a. Occurrence of Vibrio parahaemolyticus in Dutch mussels. Appl. Environ. Microbiol. 37. 438-442.

van den Broek, M.J.M., A.E. Eggenkamp, I. Eelderink and M.E. Verouden, 1979b. The microbial association of bivalve shellfish intended for consumption in the raw state with particular reference to safety. Arch. Lebensmittelhyg. 30, 98-103.

van Spreekens, K.J.A., 1974. The suitability of a modification of Long and Hammers medium for the enumeration of more fastidious bacteria from fresh fishery products. Arch. Lebensmittelhyg. 25, 213-219.

van Spreekens, K.J.A., 1977. Characterization of some fish and shrimp spoiling bacteria. Antonie van Leeuwenhoek 43, 283-303.

Warenwet, 1935 Stb. 793, edited by P.L. de Weever and H.T.M. Bleijs. 1983, Vermande Zonen, IJmuiden, $16 \mathrm{pp}$. 